\title{
PEMANFAATAN RELAI TUNDA WAKTU DAN KONTAKTOR PADA PANEL HUBUNG BAGI (PHB) UNTUK PRAKTEK PENGHASUTAN STARTING MOTOR STAR DELTA
}

\author{
Oleh \\ I Gede Siden Sudaryana \\ Jurusan Pendidikan Teknik Elektro Fakultas Teknik dan Kejuruan \\ Universitas Pendidikan Ganesha \\ ledoenk@gmail.com
}

\begin{abstract}
ABSTRAK
Tujuan dari pemanfaatan relai tunda watu selanjutnya disebut TDR (Time Delay Relay) dan kontaktor adalah sebagai salah satu modul pembelajaran mahasiswa di Laboratorium Teknik Tenaga Listrik sebagai pendukung mata kuliah Panel Hubung Bagi (PHB). Selama ini pemahaman yang dimiliki mahasiswa mengenai sistem kerja TDR dan kontaktor belum maksimal, yang menyebabkan mahasiswa belum siap diterjunkan ke lapangan dunia industri, dikarenakan kurangnya modul praktek di Laboratorium. Berdasarkan hal tersebut perlu dirancang dan dibuat suatu alat berupa Modul Praktek sebagai media pembelajaran tentang pengoperasian TDR dan kontaktor. Modul Praktek ini disusun dalam bentuk modul pembelajaran yang berisi uraian materi, tentang operasi sistem kunci rangakaian Otomatisasi Lampu Taman, sistem Direct On Line (DOL), sistem Interlock hidup secara bergantian, Interlock hidup berurutan, Putar balik Motor, penghasutan/starting motor Star-Delta. Pada kesempatan ini akan dibahas tentang pemanfaatan TDR dan Kontaktor dimana komponen-komponen tersebut adalah sebagai rangkaian kontrol yang dipergunakan pada pengendali sistem penghasutan starting motor star-delta. Sistem hidup berurutan saat push button ON ditekan yaitu rangkaian kontaktor K1 dan K2 yang akan menghubungkan rangkaian motor star, sedang rangkaian kontaktor K1 dan K3 yang akan menghubungkan rangkaian motor menjadi delta. Operasi kontaktor K2 dan K3 bekerja secara berurutan/bergantian. Jika push button OFF ditekan maka semua kontaktor akan terputus. Sistem hidup bergantian menggunakan sistem Interlock dimana $\mathrm{K} 2$ dan $\mathrm{K} 3$ tidak boleh hidup bersamaan, dimana $\mathrm{K} 3$ akan mengalami penundaan waktu selama 5 detik setelah K2 bekerja, sedangkan kontaktor K1 tetap bekerja dengan sistem Direct On Line (DOL). Penundaan waktu bekerjanya kontaktor K3 setelah K2 terputus secara automatis, dengan menggunakan komponen TDR (Time Delay Relay). Hasilnya, dengan pemanfaatan TDR pada rangkaian star-delta mahasiswa lebih mengerti cara kerja rangkaian, dapat dilihat dengan adanya peningkatan nilai mahasiswa semester genap 2014/2015 sebesar $13,82 \%$ dari semester sebelumnya genap 2013/2014, yaitu dari $82,61 \%$ menjadi $96,43 \%$.
\end{abstract}

Kata kunci : PHB, Relai Tunda Waktu, Kontaktor

\begin{abstract}
The purpose of the use of time delay relays hereinafter called TDR (Time Delay Relays) and the contactor is as one of the learning modules for students in Electrical Power Engineering Laboratory as a supporter of subjects Panel Hubung Bagi (PHB). During this understanding possessed by students regarding work TDR system and the contactor is not maximized, leading to students not yet ready to be deployed to the field of industrial world, due to lack of practice in laboratory module. Based on this need to be designed and manufactured a device such as a media module Practice learning about the operation of TDR and contactors. Practice module is structured in the form of learning modules which contain descriptions of matter, about the operation of key system automation Garden Lights series, the system Direct On Line (DOL), living alternately Interlock system, Interlock live sequence, Rewind Motor, incitement / motor starting Star- Delta. On this occasion will discuss the use of TDR and Contactors where these
\end{abstract}


components are a control circuit used in the system controller incitement star-delta motor starting. Sequentially living system when the push button is pressed ON is a series of contactors $\mathrm{K} 1$ and $\mathrm{K} 2$ will connect the motor circuit star, was a series of contactors K1 and $\mathrm{K} 3$ which will connect the motor circuit into a delta. Operation contactors K2 and K3 work sequentially / turn. If the OFF push button is pressed then all the contactor will be disconnected. Alternately living systems using interlock systems where K2 and K3 should not live together, where K3 will experience a delay time for 5 seconds after K2 work, while the contactors K1 continue to work with the system Direct On Line (DOL). K3 contactor operation delay time after K2 disconnected automatically, using components of TDR (Time Delay Relays). The result, with the use of TDR in a series of star-delta students better understand the workings of the circuit, can be seen with the increase in the value of student semester $2014 / 2015$ amounted to $13.82 \%$ from the previous semester even $2013 / 2014$, ie from $82.61 \%$ to $96,43 \%$.

Keywords: PHB, Time Delay Relays, Contactors

\section{PENDAHULUAN}

Perangkat Hubung Bagi merupakan suatu perlengkapan untuk mengendalikan, membagi tenaga listrik atau melindungi sirkuit pemanfaat tenaga listrik. Adapun bentuknya dapat berupa box panel, atau lemari. Panel Hubung Bagi (PHB) adalah peralatan yang berfungsi menerima energi listrik dari PLN dan selanjutnya mendistribusikan, sekaligus mengontrol penyaluran energi listrik tersebut melalui sirkit panel utama dan cabang ke PHB cabang atau langsung melalui sirkuit akhir kebeban yang berupa beberapa titik lampu dan kotak-kontak keperalatan listrik yang berada dalam bangunan. Kontaktor merupakan komponen dari PHB yaitu sejenis saklar yang bekerja secara magnetik dimana kontak akan bekerja apabila kumparan diberi tegangan. Kontaktor magnetis sebagai alat yang digerakkan secara magnetis untuk menyambung dan membuka rangkaian daya listrik tanpa merusak beban-beban seperti lampu, pemanas, transformator, kapasitor, dan motor listrik.

Relay yang fungsi dasarnya secara umum adalah sebagai saklar. Begitu pula dengan TDR (Time Delay Relay) sebagai saklar dimana kontak akan bekerja dipengaruhi oleh waktu yang ditentukan apabila kumparan diberi tegangan. Untuk dapat memanfaatkan TDR (Time Delay Relay) dan kontaktor secara tepat dibutuhkan pemahaman yang luas tentang bagian-bagian penyusunanya. Selama ini pemahaman teoritis yang dimiliki oleh mahasiswa mengenai kontaktor dan TDR (Time Delay Relay) terkesan kurang. Berdasarkan permasalahan diatas penulis merasa perlu untuk membuat suatu modul praktek tentang pengoperasian kontaktor dan TDR (Time Delay Relay).

Bahan ajar ini disusun dalam bentuk modul praktek atau paket pembelajaran yang berisi uraian materi, untuk mendukung penguasaan kompetensi tertentu yang ditulis secara sistematis dan sesuai dengan kajian teori pada mata kuliah PHB. Pembuatan modul praktek pembelajaran ini membahas Pemanfaatan TDR (Time Delay Relay) dan cara 
kerja kontaktor pada rangkaian Starting Motor star-delta. Yang diharapkan dari modul praktek ini adalah penguasaan keterampilan-keterampilan untuk menunjang pemenuhan kompetensi dalam menggunakan kontaktor dan TDR (Time Delay Relay). Dengan adanya alat ini sebagai modul praktek pembelajaran diharapkan dapat mengatasi permasalahan yang dialami khususnya pada mata kuliah Panel Hubung Bagi.

Sesuai dengan SAP mata kuliah PHB (Panel Hubung Bagi) dengan kode PTE-1265 pada Fakultas Teknik dan Kejuruan Universitas Pendidikan Ganesha dimana dalam mata kuliah ini standar kompetensi yang diharapkan adalah : mahasiswa memahami ketentuan umum PHB, macam-macam PHB, komponen yang terpasang pada PHB, lemari hubung bagi, kotak hubung bagi, panel pengatur mesin listrik, panel kontrol, panel pengaturan berurutan, panel pengaturan interlock dan panel pengasutan motor listrik. Pada mata kuliah PHB selain pembelajaran tentang kajian teori/pustaka, juga disertai-praktek. Adapun praktek sesuai dengan Teori diktat PHB yang ditulis oleh Ratnaya diantaranya praktek Rangakaian Otomatisasi Lampu Taman, sistem Direct On Line (DOL), sistem Interlock hidup secara bergantian, Interlock hidup berurutan, Putar balik Motor, penghasutan/starting motor Star-Delta. Praktik pada kuliah PHB tersebut diatas detikik beratkan pada sistem kontrol daya berupa beban penerangan lampu dan Mesin Listrik skala besar, sistem kontrol yang dimaksud adalah Panel Kontrol bentuknya dapat berupa box panel, atau lemari perangkat Hubung Bagi dan selanjutnya disebut Panel Hubung Bagi (PHB).

PHB adalah Panel Hubung Bagi dibedakan sebagai Panel Utama/MDP (Main Distribution Panel), Panel Cabang/SDP (Sub Distribution Panel), dan Panel Beban/SSDP (Sub-sub Distribution Panel), yang semuanya mempunyai fungsi sebagai Penghubung, Pengaman, Pembagi, Pensupplay dan penguntrol. Panel sebagai Penghubung yaitu : berfungsi untuk menghubungkan antara satu rangkaian listrik dengan rangkaian listrik lainnya pada suatu operasi kerja dan menghubungkan suplai tenaga listrik dari panel utama sampai ke beban-beban baik instalasi penerangan maupun instalasi tenaga. Panel sebagai Pengaman yaitu : suatu panel akan bekerja secara otomatis melepas sumber atau suplai tenaga listrik apabila terjadi gangguan pada rangkaian. Pada panel ini yang berfungsi sebagai pengaman listrik adalah MCCB dan MCB. Panel sebagai Pembagi yaitu : membagi kelompok beban baik pada instalasi penerangan maupun pada instalasi tenaga, memisahkan atau membagi suplai tenaga listrik berdasarkan jumlah beban dan banyak ruangan yang merupakan pusat beban yang dibagi menjadi beberapa group beban dan juga untuk membagi fasa $R$, fasa $S$, fasa $T$ agar mempunyai beban yang seimbang antar fasa. Panel sebagai pensuplai yaitu : mensuplai tenaga listrik dari sumber ke beban, 
dan mendistribusikan tenaga listrik dari panel utama, panel cabang sampai ke pusat beban baik untuk instalasi penerangan maupun instalasi tenaga. Panel sebagai Pengontrol merupakan fungsi paling utama, karena dari panel tersebut masing-masing rangkaian beban dapat dikontrol sehingga seluruh beban pada bangunan baik instalasi penerangan maupun instalasi tenaga dapat dikontrol dari satu tempat.

Panel-panel/sub panel diatas terdiri dari beberapa komponen yang saling bekerja sama. Adapun komponen-komponen utama yang dibahas dalam kajian pustaka ini adalah MCB, Relai, Magnet Contactor (MC), dan saklar tombol tekan. MCB adalah suatu rangkaian pengaman yang dilengkapi dengan komponen thermis (bimetal) dan relai elektromagnetik. Pengaman termis berfungsi untuk mengamankan arus beban lebih sedangkan pengaman elektromagnetis berfungsi untuk mengamankan jika terjadi hubung singkat. MCB banyak digunakan untuk pengaman sirkit satu fasa dan tiga fasa. MCB dapat memutuskan rangkaian tiga fasa walaupun terjadi hubung singkat pada salah satu fasanya. MCB dibuat hanya memiliki satu kutub untuk pengaman satu fasa, sedangkan untuk pengaman tiga fasa biasanya memiliki tiga kutub dengan tuas yang disatukan, sehingga apabila terjadi gangguan pada salah satu kutub maka kutub yang lainnya juga akan ikut terputus. MCCB merupakan salah satu alat pengaman yang dalam proses operasinya mempunyai dua fungsi yaitu sebagai pengaman dan sebagai alat untuk penghubung. Jika dilihat dari segi pengaman, maka MCCB dapat berfungsi sebagai pengaman gangguan arus hubung singkat dan arus beban lebih. Pada jenis tertentu, pengaman ini mempunyai kemampuan pemutusan yang lebih besar dari MCB.

Relay adalah Saklar (Switch) yang dioperasikan secara listrik dan merupakan komponen Electromechanical (Elektromekanikal) yang terdiri dari 2 bagian utama yakni Elektromagnet (Coil) dan Mekanikal (seperangkat Kontak Saklar/Switch). Relai menggunakan Prinsip Elektromagnetik untuk menggerakkan Kontak Saklar sehingga dengan arus listrik yang kecil (low power) dapat menghantarkan listrik yang bertegangan lebih tinggi. Sebagai contoh, dengan Relai yang menggunakan Elektromagnet 5Volt : 50 mA mampu menggerakan Armature Relai (yang berfungsi sebagai saklarnya) untuk menghantarkan listrik 220V 2A. Karena Relai merupakan salah satu jenis dari Saklar, maka istilah Pole dan Throw yang dipakai dalam Saklar juga berlaku pada Relai. Berikut ini adalah penjelasan singkat mengenai Istilah Pole and Throw. Pole yaitu banyaknya kontak (Contact) yang dimiliki oleh sebuah relai, sedang Throw adalah banyaknya kondisi yang dimiliki oleh sebuah Kontak (Contact). Berdasarkan penggolongan jumlah Pole dan Throw-nya sebuah relai, maka relai dapat digolongkan menjadi (A) Single Pole Single Throw (SPST) relai golongan ini memiliki 4 Terminal, 2 Terminal untuk Saklar 
dan 2 Terminalnya lagi untuk Coil. (B) Single Pole Double Throw (SPDT) adalah relai yang memiliki 5 Terminal, 3 Terminal untuk Saklar dan 2 Terminalnya lagi untuk Coil. (C) Double Pole Single Throw (DPST) yaitu Relai yang memiliki 6 Terminal, diantaranya 4 terminal yang terdiri dari 2 pasang terminal saklar, sedangkan 2 Terminal lainnya untuk Coil. Relai DPST dapat dijadikan 2 Saklar yang dikendalikan oleh 1 Coil. (D) Double Pole Double Throw (DPDT) relai golongan ini memiliki terminal sebanyak 8, diantaranya 6 terminal yang merupakan 2 pasang Relai SPDT yang dikendalikan oleh 1 (single) Coil. Sedangkan 2 Terminal lainnya untuk Coil.

Magnetic Contactor (MC) adalah sebuah komponen yang berfungsi sebagai penghubung/ kontak dengan kapasitas yang besar dengan menggunakan daya minimal. Dapat dibayangkan MC adalah relai dengan kapasitas arus yang lebih besar. Umumnya MC terdiri dari 3 pole kontak utama (main contact) dan kontak bantu (auxiliary contact). Untuk menghubungkan kontak adalah dengan cara memberikan tegangan pada koil MC sesuai spesifikasinya. Fungsi dari Kontak utama tendiri dari kontak tiga NO dan kontak bantu terdiri dari kontak NO dan NC. Kontak utamanya mempunyai luas bidang kontak lebih luas dan tebal sedang kontak bantu lebih kecil dan tipis. Kontak utama digunakan untuk mengalirkan arus utama untuk aliran 3 fasa, misalnya motor listrik, pesawat pemanas dan sebagainya, sedangkan kontak bantu digunakan untuk mengalirkan arus bantu yaitu arus kontrol dan sinyal yang diperlukan untuk rangkaian utama. Kontak Normally Open $=$ NO berarti saat kontaktor magnet belum bekerja kedudukan kontak membuka, bila kontaktor bekerja kontak itu menutup/menghubung. Sedang kontak Normally Close $=\mathrm{NC}$, berarti saat kontaktor nomal/belum bekerja kedudukan kontaknya menutup dan bila kontaktor bekerja kontak itu membuka.

Saklar tombol tekan (Push button) adalah saklar tekan yang berfungsi untuk menghubungkan atau memisahkan bagian-bagian dari suatu instalasi listrik satu sama lain. Prinsip kerja Push Button yaitu : (a) Tipe Normally Open (NO) Tombol ini disebut juga dengan tombol start karena kontak akan menutup bila ditekan dan kembali membuka saat dilepas. Bila tombol ditekan maka kontak bergerak dan menyentuh kontak tetap sehingga arus listrik akan mengalir (ON). (b) Tipe Normally Close (NC) Tombol ini disebut juga dengan tombol stop karena kontak akan membuka bila ditekan dan kembali menutup bila dilepaskan. Kontak bergerak akan lepas dari kontak tetap sehingga arus listrik akan terputus $(O F F)$. (c) Tipe NC dan NO Tipe ini kontak memiliki 4 buah terminal, sehingga bila tombol tidak ditekan maka sepasang kontak akan NC dan kontak lain akan NO, sebaliknya bila tombol ditekan maka kontak NC akan membuka dan kontak NO akan menutup. 


\section{METODE PENELITIAN}

Adapun Metode yang digunakan adalah studi dokumen dari beberapa dokumen yang ada di Jurusan Pendidikan Teknik Elektro yang terkait dengan aplikasi atau penggunaan relai, studi beberapa tugas akhir mahasiswa yang terkait dengan penggunaan relai, dan studi kepustakaan dari beberapa buku yang mengulas tentang PHB. Perencanaan dan pembuatan modul praktek ini adalah bersifat praktis, yaitu membahas dan merencanakan pada pembuatan alat/modul praktek secara nyata yaitu melakukan pendekatan dengan cara membuat prototype, sistem dan model miniaturnya. Hal ini dimaksudkan untuk memperkenalkan konsep - konsep yang dapat dimengerti dan dapat diterapkan pada tiap tahapan sistem yang lebih besar dan kompleks, baik dari segi perangkat mekanik maupun perangkat elektroniknya.

Perancangan modul PHB ini dimulai dengan merancang modul di atas kertas. Komponen yang digunakan disesuaikan dengan aplikasi dan perletakan komponen agar memberikan hasil sesuai harapan, kemudian membuat rancangan modul Praktek PHB untuk pengoperasian starting motor Star-delta. Untuk dapat lebih jelasnya gambar rangkaiannya adalah sebagai berikut.

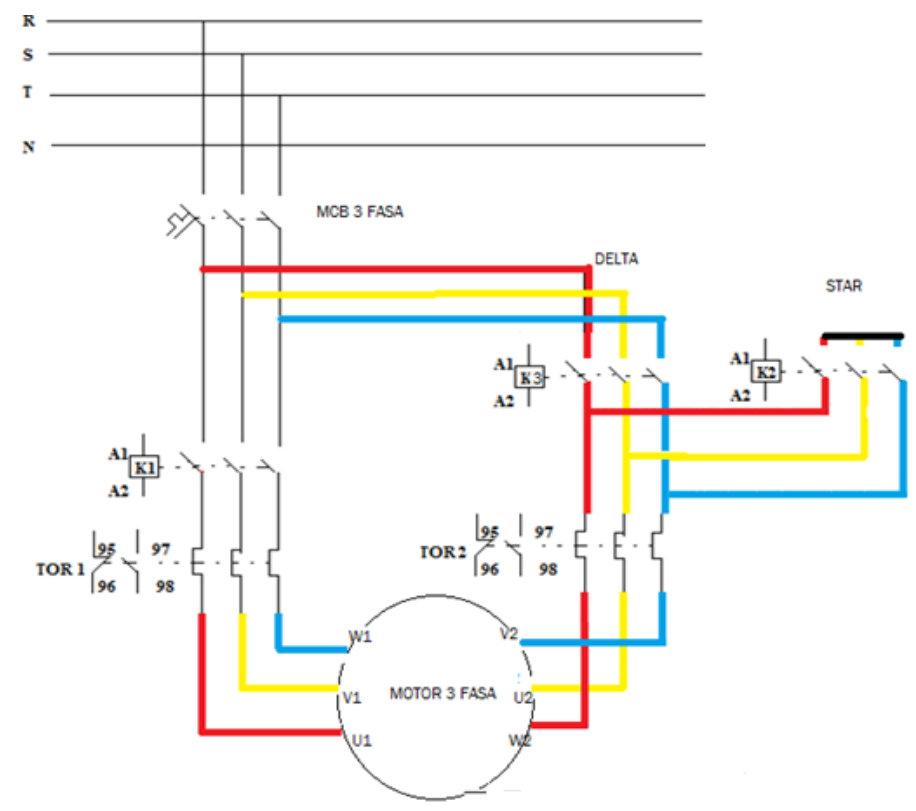

Gambar 1 Rangkaian utama atau wiring diagram Startting Motor Star-delta : 


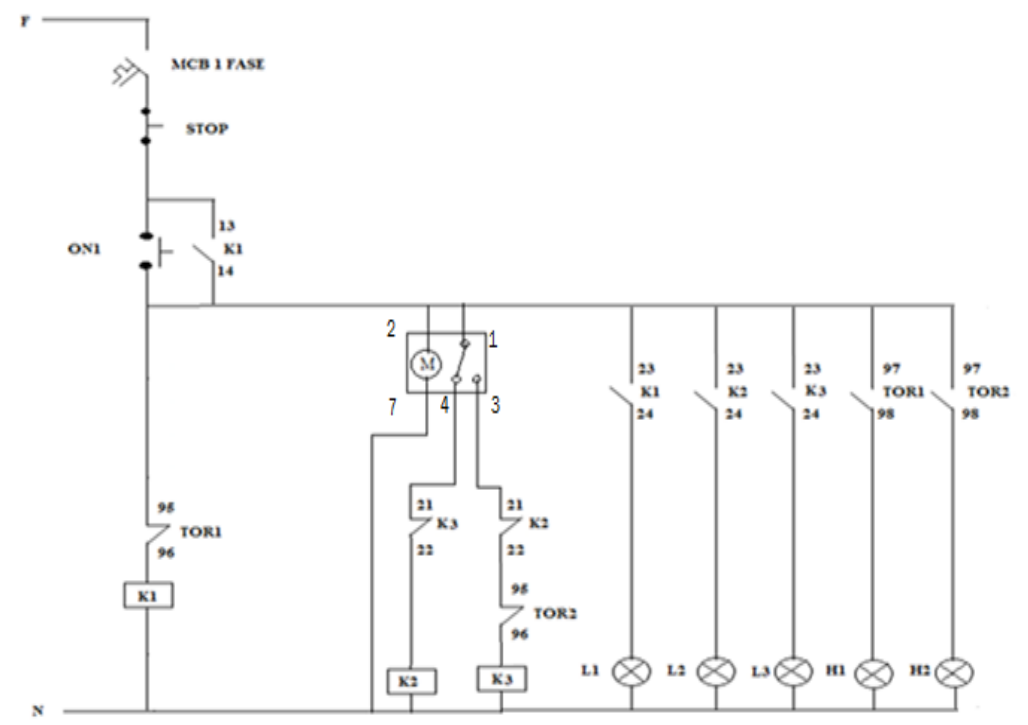

Gambar 2 Rangkaian Kontrol Startting Motor Star-delta ::

\section{HASIL DAN PEMBAHASAN}

Hasil yang bisa diperoleh dengan adanya pembuatan Modul Praktek ini adalah mahasiswa dapat melihat secara langsung sistem kerja rangkaian, sehingga lebih mudah memahami dan mengerti cara kerja rangkaian. Hal ini dilihat dari nilai prestasi mahasiwa yang meningkat 1 tahun kedepan meningkat sebesar 13,82. Dimana pada semester genap 2013/2014 adalah 82,61\% dan semester genap 2014/2015 sebesar 96,43\%.

Pemahaman tentang PHB, rangkaian utama, rangkaian kontrol, wiring diagram, prinsip kerja dan cara kerja rangkaian maupun prinsip kerja komponen sudah didapatkan pada kajian teori/perkuliahan PHB misalnya, Rangakaian Otomatisasi Lampu Taman, sistem Direct On Line (DOL), sistem Interlock hidup secara bergantian, Interlock hidup berurutan, Putar balik Motor, penghasutan/starting motor Star-Delta. Berbekal dengan teori dan kajian pustaka yang didapatkan pada mata kuliah PHB, pada kesempatan ini akan dibahas tentang pemanfaatan TDR (Time Delay Relay) dan Kontaktor sebagai komponen kontrol pada modul praktek Penghasutan starting mesin/motor Star Delta. Penghasutan motor star-delta artinya rangkaian motor dihubungkan secara Star pada saat starting, dan dihubungkan delta pada saat running dengan tujuan untuk mengurangi arus start yang masuk ke motor. Pemilihan TDR (Time Delay Relay) yang tepat adalah dengan pemanfaatan Relai Omron H3CR-A8 digunakan sebagai kompenen kontrol pada penghasutan starting motor dimana, waktu yang diperlukan untuk perpindahan dari star ke delta yang tergantung dari beban motor, dimana semakin besar beban motor maka diperlukan waktu tunda (delay) yang lama untuk merubah rangkaian dari star ke delta, begitu sebaliknya. Omron H3CR Sebagai TDR (Time Delay Relay) banyak digunakan 
dalam instalasi motor listrik terutama instalasi yang membutuhkan pengaturan waktu secara otomatis. Peralatan kontrol ini dapat dikombinasikan dengan MC (Magnetic Contactor), Thermal Over Load Relay, dan lain-lain. Fungsi dari TDR (Time Delay Relay) ini adalah sebagai pengatur waktu bagi peralatan yang dikendalikannya. Timer ini dimaksudkan untuk mangatur waktu hidup atau mati dari kontaktor, dimana bagian input biasanya dinyatakan sebagai kumparan (coil) dan bagian outputnya sebagai kontak NO atau NC. Kontak NO dan NC akan bekerja ketika timer diberi ketetapan waktu. Ketetapan waktu ini dapat kita tentukan pada potensiometer yang terdapat pada Relay timer H3CR itu sendiri. Misalnya ketika kita telah menetapkan 5 detik, maka kontak NO dan NC akan bekerja 5 detik setelah kita menghubungkan timer dengan sumber arus listrik. Pengaturan waktu yang dapat di-setting sesuai dengan keinginan, dimana rentangnya dari detik terkecil sampai puluhan jam (x10 jam) terbesar yang menjadikan realy ini banyak dipergunakan pada bermacam-macam aplikasi.

Relai Omron H3CR-A8, yang memiliki 8 pin atau kaki , 2 pin diantaranya merupakan input ke koil yaitu kaki 2 dan 7, sedangkan kaki yang lain adalah out put switch yang berpasangan secara NO dan NC. Dimana kaki tengah adalah 1 dan 8, kakikaki lainya 1-4 dan 8-5 terhubung secara NC. Sedangkan yang terhubung secara NO adalah kaki 1-3 dan 8-6. Selengkapnya hubungan 8 pin yang dimaksud dapat diperhatikan

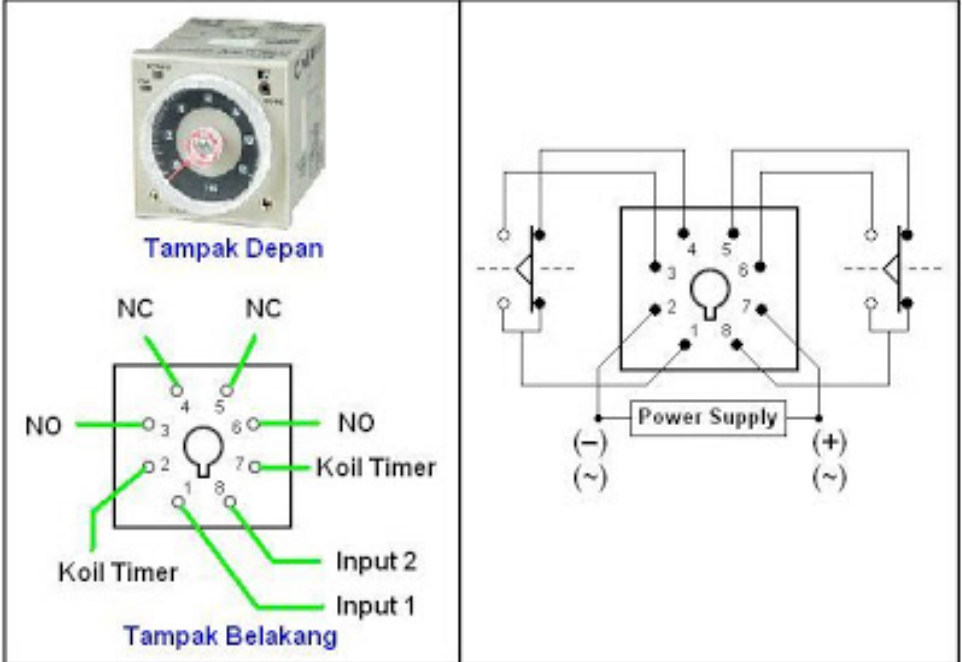

Gambar 3 Wiring diagram Relay Omron H3CR-A8 pada gambar di bawah.

Prinsip kerja komponen dimana kakikaki pada relay ini terhubung NC maupun NO tergantung dari pengoperasian /mode relay tersebut baik digunakan sebagai time delay, timer bergantian/berurutan (fliker) atau switch $\mathrm{ON}$ (one shot). Untuk keterangan gambar relai Omron H3CR-A8 dapat dijelaskan sebagai berikut :

(1)Skala penunjukan relai timer, (2)Pengaturan skala pewaktuan bisa detik, detik, jam, dan 10xjam, (3)Pengaturan skala angka bisa 0-1.2, 0-3, 0-12, dan 0-30, (4)Pengaturan 
mode timer bisa A, B2, E, dan J, (5)Lampu power timer saat mendapatkan catuan DC

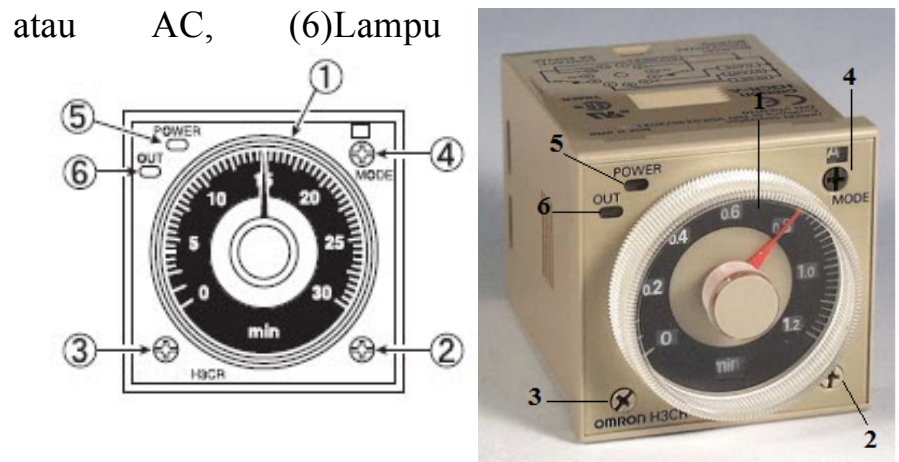

Gambar 4 Indikator dan konstruksi Relay Omron H3CR-A8 penunjukan timer saat penghitungan mundur habis.

\section{Pemilihan}

Pengoperasian (mode) pada relay omron $\mathrm{H} 3 \mathrm{CR}-\mathrm{A} 8$ dapat dilakukan dengan cara memutar menggunakan obeng . Timer tersebut memiliki 4 mode A, B2, E, dan J. Masing-masing mode

memiliki fungsi sendiri, yaitu (1) Mode A adalah On Delay, misal timer diset selama 5 detik, ketika arus listrik mengalir ke koil timer dan relay mulai menghitung selama 5 detik, pada saat itu output berupa kontak NO akan bekerja menutup. Kondisi relay difungsikan sebagai "ON Delay", artinya menunggu selama 5 detik untuk menutup kontak NO sehingga arus mengalir ke beban. (2) Mode B2 adalah Off Delay, Mode ini bila diset waktu 5 detik, ketika koil Timer diberi tegangan, seketika itu kontak NO menutup, maka arus dapat mengalir kebeban. Sampai 5 detik kemudian kembali kontak NO membuka. Kondisi ini adalah "OFF Delay, sehingga arus terputus ke rangakaian. artinya menunggu 5 detik untuk membuka kontak NO. (3) Mode E adalah Interval bergatian, missal mode ini diset waktunya selama 5 detik maka ketika timer bertegangan maka kontak NO akan menutup selama 5 detik, kemudian 5 etik berikutnya Kontak NO akan terbuka. 5 detik berikutnya kembali kontak NO menutup. Begitu setrusnya dengan interval waktu selama 5 detik. (4) Mode J : One Shot Output diset selama 5 detik, ketika koil timer bertegangan, maka selang waktu 5 detik kita menunggu kontak NO untuk menutup. Kontak NO akan menutup selama 1 detik dan setelah itu kontak NO kembali terbuka, artinya picuan hanya diberikan sekali saja selama 1detik, dengan delay/tunggu selama 5 detik.

Rangkaian starting motor star-delta terdiri dari rangkaian control, rangkaian utama atau wiring diagram. Mengontrol berarti mengendalikan atau mengatur, jadi ketika kita bicara tentang kontrol motor atau mesin, kita membahas mengenai pengendalian dan pengaturan fungsi dari motor atau mesin tersebut yang melakukan beberapa fungsi misalnya seperti starting, pengatur kecepatan, sistem proteksi, putar balik dan stoping. Rangkaian inilah yang akan mengontrol dapa rangkaian utama.

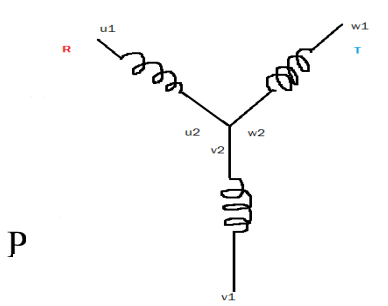

Dengan menghidupkan terlebih dahulu MCB 3 fasa, 
dimana saat $\mathrm{MC}(\mathrm{K} 1)$ bekerja mendapat tegangan dari rangkaian control, menyebabkan arus mengalir dari sumber tegangan 3 fase (R, S, dan T) melewati MCB 3 fase menuju kontak utama MC (K1) yaitu kontak NO (1-2, 3-4, dan 5-6), melewati bimetal TOR1 dan mengalir ke motor, terminal motor U1,V1,W1. Pada saat bersamaan MC (K2) mendapat supply tegangan menyebabkan $\mathrm{MC}$ (K2) berkerja menghubungkan terminal motor V2, W2, U2 terkople menjadi rangkaian star.

Beberapa saat sesuai dengan waktu yang telah ditentukan (delay waktu yang ditentukan) time delay akan memutuskan arus menuju MC (K2) dan menguhubungkan MC (K3) meyebabkan, kontak MC (K2) terbuka memutuskan rangkaian Start dan MC (K3) bekerja menutup kontak utamanya menghubungkan terminal motor $\mathrm{V} 2$, $\mathrm{U} 2$, W2 dengan sumber $\mathrm{R}, \mathrm{S}$, T, sehingga motor bekerja sebagai rangkaian delta. (running).

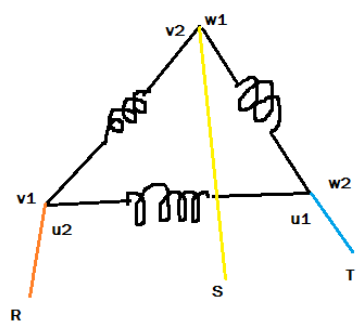

Gambar 5 hubung delta

Sedangkan untuk rangkaian kontrol, Rangkaian ini bertujuan mengontrol MC (Magnet Contactor) pada rangkaian utama yang terdiri dari 3 buah MC (K1, K2, K3), dimana pada saat $\mathrm{K} 1$ dan K2 bekerja maka rangkaian motor terhubung bintang, sedangkan bila K1 dan K3 bekerja maka motor terhubug bintang.

Menghubungkan MCB 1 fasa dengan sumber tegangan terlebih dahulu, kemudian menekan sesaat push button ON1 yang menyebabkan arus mengalir dari sumber tegangan (F) melalui MCB 1 fase, push button stop, push button ON1, TOR 1, menuju koil pada MC (K1) sehingga bertegangan dan bekerja. Bekerjanya MC (K1) menyebabkan kontakkontak NO baik pada kontak utama dan kontak bantu terhubung (berubah menjadi NC). Kontak bantu pada K1 (13-14) yang awalnya terbuka akan tertutup, sehingga arus akan tetap mengalir menuju K1, walaupun push button ON1 telah selesai ditekan. Berlaku juga pada kontak bantu K1 (23-24) akan tertutup dan menghidupkan lampu L1 yang menandakan bahwa K1 bekerja. Pada saat bersamaan arus juga mengalir menuju TDR (Time Delay Relay) dan bekerja (mulai mengitung mundur) dimana kontak timer 1-4 pada kondisi NC menyebabkan arus mengalir menuju kontak bantu (NC) pada K3 (2122), dan menyebabkan MC K2 bertegangan dan bekerja. Bekerjanya MC K2 menyebabkan kontak utama dan bantu berubah kondisi yang awalnya terbuka menjadi tertutup begitu juga sebaliknya. Kontak bantu K2 (23-24) akan tertutup dan arus mengalir menuju lampu indikator L2 dan menyala menandakan bahwa K2 bekerja. Kontak bantu K2 (21-22) akan terbuka untuk memastikan MC K3 tidak dapat bekerja, saat ini motor akan terhubung bintang (star) selama penghitungan mundur dari TDR (Time Delay Relay). 
Ketika perhitungan mundur selesai sesuai setting waktu yang diinginkan, dimana kontak timer 1-4 pada kondisi NC berubah menjadi NO, dan menutup kontak relai 1-3 menyebabkan aliran arus menuju MC (K2) terputus. Terputusnya MC K2 menyebabkan terputusnya kontak bantu K2 (23-24) sehingga lampu L2 padam. Selanjutnya arus mengalir menuju MC (K3) melalui NC pada K2 dan TOR, menyebabkan MC K3 bekerja, begitu juga kontak bantu K3 (23-24) terhubung menghidupkan lampu L3. Sehingga rangkaian pada saat ini akan menghubungkan motor menjadi delta.

Penambahan kontak-kontak NC pada K2 dan K3 yang saling bertautan pada masing masing kontaktornya dimana arus listrik akan mengalir terlebih dahulu pada $\mathrm{NC}$ K3 sebelum masuk koil K2, begitu juga sebaliknya. Hal ini semata-mata untuk menghindari terjadinya kedua kontaktor itu bekerja secara bersamaan.

Proteksi oleh TOR (Thermal Over load Relai) bekerja bila pada rangkaian utama terjadi ganggguan arus lebih pada beban motor, elemen bimetal TOR1 akan melengkung dan membuat kontak NC 95-96 terbuka (menjadi NO) dan kontak NO 97-98 tertutup (menjadi NC). Kontak TOR1 95-96 yang terbuka akan memutus suplai arus MC (K1), kontak utama dan kontak bantu K1 kembali kekeadaan normal sehingga lampu indikator L1 dan motor akan OFF karena tidak mendapatkan suplai arus. Kontak TOR1 97-98 yang tertutup akan membuat arus mengalir menuju lampu indikator H1 dan membuat lampu indikator tersebut bekerja.

Dari penjelasan diatas berhubungan dengan komponen yang digunakan dan jumlah komponen pada rancangan pembutan modul ini termasuk alat dan bahan yang digunakan yaitu : 1 buah MCB 1 Fase, 1 buah MCB 3 fase, 3 buah Magnet Kontaktor, 1 buah Push Button Off, 1 buah Push Button On, 3 buah Thermal Overload Relai, 1 buah Relai H3CRA8, 1 buah Motor 3 fase, 1 buah Multi Meter, 3 buah Lampu Indikator, Tang Kombinasi, Test Pen, Obeng (+) dan (-),Cutter, Kabel jumper secukupnya.

\section{SIMPULAN}

Dengan adanya modul ini mahasiswa dapat dengan jelas melihat dan mengamati kerja rangkaian relai Omron H3CR pada rangakain Star-Delta adalah sebagai TDR (Time Delay Relay) yaitu menunda waktu rangkaian starting menjadi rangkaian running pada penghasutan motor listrik 3-phase, dimana TDR berfungsi menunda waktu sesuai dengan setting waktu yang ditentukan, ini terlihat pada pengujian Modul Praktek dimana K1 dan K2 bekerja menghubungkan bintang pada saat starting, kemudian akan menghubungkan delta pada saat running dengan bekerjanya K3. Hasil pengamatan mahasiswa dan pengertian yang bertambah menyebabkan perolehan nilai kelulusan mahasiswa 
meningkat $13,82 \%$. dari sebelumnya pada semester genap 2013/2014 hanya $82,61 \%$ kemudian meningkat menjadi 96,43\% pada semester genap 2014/2015.

\section{DAFTAR PUSTAKA}

Omron Industrial Automation Products (2014). Manual book Solid-state Multi-functional Timers H3CR-A. OMRON Corporation 2007 - 2015.

P. Van. Harten, Ir. E Setiawan (1995). Instalasi Listrik Arus Kuat 3. Binacipta, Bandung.

Ratnaya, I Gede. (2005). Diktat Mata Kuliah Panel Hubung Bagi (PHB) Jurusan Teknik Elektro Universitas Pendidikan Ganesha.

Sumahendra, Wayan (2010) Tugas Akhir Simulasi Pembelajaran Panel Hubung Bagi Menggunakan Rangkaian Kontaktor dan Relay Jurusan Teknik Elektro Universitas Pendidikan Ganesha.

Dickson Kho in Komponen Elektronikahttp://teknikelektronika.com (2015) pengertianrelay-fungsi-relay. Teknik Elektronika Manejemen Produksi dan statistika.

Rekayasa Listrik in Kontaktor https://rekayasalistrik.wordpress.com/2013/03/03/carakerja-kontaktor/ 